\title{
Artelogie
}

artelogie Recherche sur les arts, le patrimoine et la littérature de l'Amérique latine

$6 \mid 2014$

Horizons et dispositifs des arts plastiques des pays du Río de la Plata (XXe siècle)

Del cristianismo a la teosofía: "Père Soleil" de Joaquín Torres-García

\section{Edgard Vidal}

\section{(2) OpenEdition \\ Journals}

Edición electrónica

URL: http://journals.openedition.org/artelogie/1550

DOI: $10.4000 /$ artelogie. 1550

ISSN: 2115-6395

Editor

Association ESCAL

Referencia electrónica

Edgard Vidal, « Del cristianismo a la teosofía: "Père Soleil” de Joaquín Torres-García », Artelogie [En línea], 6 | 2014, Publicado el 24 junio 2014, consultado el 03 mayo 2019. URL : http://

journals.openedition.org/artelogie/1550; DOI : 10.4000/artelogie.1550

Este documento fue generado automáticamente el 3 mayo 2019.

Association ESCAL 


\title{
Del cristianismo a la teosofía: "Père Soleil" de Joaquín Torres-García
}

\author{
Edgard Vidal
}

\section{Introducción}

1 Joaquín Torres-García es un creador polifacético. Cultiva diversos campos de la creación artística: pintura, fabricación industrial de juegos, libros de arte. También diversos géneros literarios tales como la teoría critica, la reflexión metafísica, el artículo periodístico, las conferencias. En su dilatada trayectoria participa de las corrientes estéticas más innovadoras de su época, coincidiendo con las inquietudes que preocupaban en aquel momento a los artistas que inventaron las grandes escuelas de la vanguardia del siglo XX : Noucentismo, Planismo, Neoplasticismo, Constructivismo.

2 Teniendo en cuenta estas premisas sobre la actitud del pintor uruguayo frente a la creación, no debe extrañar que su postura ante la religión (y como resultado de esa variedad que caracteriza su obra) no sea sólo una, sino que sea plural y diversa en sus tratamientos y en sus sucesiones. Esto significa también proximidades con algunas de las más importantes corrientes filosóficas y esotéricas que influyen en los intelectuales y artistas de la época. De acuerdo a lo mencionado más arriba, trataremos de acercarnos a las interrelaciones entre la obra constructiva y el pensamiento esotérico, concentrándonos sobre un momento muy específico de la vida del pintor. El momento de la creación del libro "Père Soleil", firmado por el autor en 1931.

3 Esta obra nos parece importante en la configuración de sus posiciones estéticas al mismo tiempo que articula dos momentos importantes de sus creencias religiosas, el cristianismo (consolidado doctrinariamente en el período de su pasaje por el círculo Saint Lluc en Barcelona) y sus simpatías por el pensamiento esotérico.

4 La importancia de las teorías teosóficas en la obra del uruguayo ha sido remarcada desde muy temprano por los críticos y los comentaristas. Juan Flo (1991) busca la significación en el autor de "Universalismo constructivo" (Torres Garcia, 1984) de esa "compleja mezcla de platonismo, ocultismo, teosofía y religiosidad sin iglesia". Sostiene que "no 
podemos ignorar los fundamentos religiosos de sus teorías, no solamente porque forman parte de los procesos subjetivos del artista que intervinieron en la producción de su obra, sino, además, porque es indispensable tenerlos en cuenta para entender la obra misma en su interrelación con el resto del arte contemporáneo y para reconocer su peculiaridad y su valor “ (Fló, 2004). Las simpatías del pintor uruguayo con este grupo esotérico están explicadas por su red de relaciones, ya que tanto Mondrian como Kandinsky, dice, muy cercanos al pintor catalán, estuvieron vinculados con la teosofía (Fló, 1991: 18). Y estas pistas serán retomadas recientemente en una nota de lectura de Nelson Di Maggio, donde insiste sobre " la poderosa influencia de Rudolf Steiner, fundador de la antroposofía, célebre personalidad a cuyas multitudinarias conferencias asistían Einstein, Xul Solar y Kandinsky, dos amigos de Torres y que en la muestra de sus pizarrones en el Museo Nacional de Bellas Artes en Buenos Aires, hace pocos años, reveló la importancia íntima entre su pensamiento y sus signos en el arte contemporáneo que se extendió hasta Joseph Beuys, su heredero legítimo" (Di Maggio, 2007). También Di Maggio menciona a Helena P. Blavatsky, la fundadora de la teosofía, cuyo pensamiento habría incidido en Gaudí, "con el cual tuvo estrecha relación en sus años mozos Torres-García, así como posteriormente en Mondrian, otro artista que conoció" (Di Maggio, 2007).

5 Marie-Aline Prat, en su renovador estudio sobre la revista "Cercle et carré", afirma que las relaciones de Torrès-Garcia (la autora escribe su nombre en catalán) con el esoterismo son indudables (Prat, 1984: 138). En su libro, analiza las relaciones de muchos de los miembros de ésta revista con el movimiento liderado por la legendaria Mme. Blavatsky. Pero muchas de las intuiciones de los críticos se quedan en declaraciones de intención y falta un trabajo en profundidad sobre las relaciones de las doctrinas teosóficas y los textos de Torres-García. Esto es lo que pretendemos desarrollar en el presente artículo.

Con este fin, hemos constituido una base de datos lexical de los términos con letras mayúsculas, donde se analiza el título, el sujeto, una descripción iconológica del grafismo, la disposición en la página y su número. Esto nos permite hacer aparecer más fácilmente las palabras consideradas importantes para el pintor y escritor constructivista. (Consulter la base)

7 Un segundo paso fué confrontar éste léxico con el corpus teosófico francés. El movimiento teosófico se formó en Nueva York en 1875. Sus fundadores, la rusa Helena Petrovna Blavatsky y el norteamericano Henry Steel Olcott, se instalan en India pero están activos en América y en Europa. Este último se vé afectado por las ideas difundidas por los dos fundadores y, en particular, por una de sus discípulas, la carismática Annie Besant. Tratando de constituir una nueva religión universal, Helena Petrovna Blavatsky y sus seguidores proponen la idea de una tradición primordial que orientaría la elaboración de cualquier religión y pretenden ampliar la religiosidad occidental con el estudio de los textos sagrados de las filosofías religiosas orientales.

En Francia esta corriente se introduce en un momento propicio (el siglo XIX) que aún recibía la influencia de algunos pensadores del siglo XVIII: Swedenborg, Saint- Martin y Mesmer. ${ }^{1}$ El esoterismo y el ocultismo también tienen suceso con escritores como Eliphas Levi y Papus. El espiritismo (creado por Allan Kardec) tiene mucho auge en la sociedad francesa, donde es practicado tanto secretamente en las reuniones espíritas como lúdicamente en las reuniones sociales.

9 Es en este contexto que se crea una sección francesa de tesofía en 1899, que se convierte en la Sociedad Teosófica de Francia en 1908. Alrededor de la editorial y la revista creadas por esta sociedad se agrupan una serie de autores con los cuales hemos confrontado la 
obra "Père Soleil" de Torres-García. Allí donde hemos encontrado mayor recurrencia de los términos utilizados por nuestro pintor, hemos tratado de analizar las proximidades semánticas de los dos textos. Los autores y los libros más cercanos al universo semántico del autor de "Père Soleil" son (ordenados por orden alfabético):

- Besant, Annie. 1912. L'avenir imminent / Annie Besant; traduit de l'anglais par Gaston Revel. Éditions théosophiques (París).

- Chevrier, Georges. 1917. La mission créatrice : plans, ego, réincarnation / Georges Chevrier. Publications théosophiques (París).

- Hartmann, Franz. 1903. La magie blanche et noire, ou la science de la vie terrestre et de la vie infinie contenant des conseils pratiques pour les étudiants de l'occultisme. Libr. de l'Art indépendant.

- Papus. 1918. Ce que deviennent nos morts; suivi de Méditations sur le "Pater" et de quelques opuscules posthumes / Papus (Dr Encausse). La Sirène (París).

- Revel, Gaston. 1913. De l'an 25.000 avant Jésus-Christ à nos jours / Gaston Revel. les Éditions théosophiques (París).

- Saint-Yves d'Alveydre, Alexandre. 1910. L'archéomètre, clef de toutes les religions et de toutes les sciences de l'antiquité, réforme synthétique de tous les arts contemporains... / Saint-Yves d'Alveydre. Dorbon aîné (París).

- Schuré, Édouard. 1912. L'évolution divine: du sphinx au Christ / Édouard Schuré. Perrin (París).

- Steiner, Rudolf. 1923. Théosophie: étude sur la connaissance suprasensible et la destinée humaine / Rudolf Steiner ; traduit de l'allemand, par Elsa Prozor. les Presses universitaires de France (París).

\section{Análisis lexical}

11 Comencemos entonces con el análisis lexical del primer grupo de sustantivos (madre padre - tierra - padre). Ellos están pautando la relación entre lo particular y lo general y, más específicamente, el microcosmos humano (la figura del padre) con el macrocosmos (el universo significado por el sol).

Figura 1 - Primer grupo lexical en PÈRE SOLEIL. Texto fechado por el autor en París, el 29 de julio 1931.

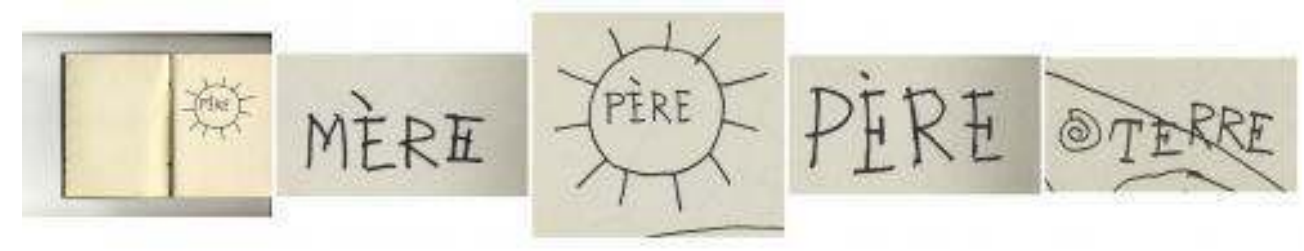

Escrito en francés. Primera edición : Fundación Torres-García, Montevideo, 1974. Formato 17 x 12,5 cm, 72 páginas no numeradas (en adelante Torres-García, Joaquín : 1931).

En efecto, estos términos no designan solamente la persona determinada de Don Joaquín Torres Fradera ni de Doña María García Pèrez (padre y madre del pintor), sino que son proyectados sobre un marco cósmico, representado por el sol que rodea la palabra "Padre", o aún por la expresión "tierra" que junto al grupo de denominativos familiares aumenta el espectro de significación, planteando las posibles relaciones de equivalencia o 
de correspondencia: sol = padre, maternidad = tierra. Las imágenes que acompañan este grupo, un ave, peces, un perro, tipifican también de manera abstracta los diferentes reinos vegetales y animales $\mathrm{y}$, al interior de éste, los tres medios: aéreo, acuático y terrestre.

Figura 2 - Conjunto de Padre, Madre y Tierra, con dibujos representando los diferentes medios ambientes y sus especies (en Torres-García, Joaquín: 1931).

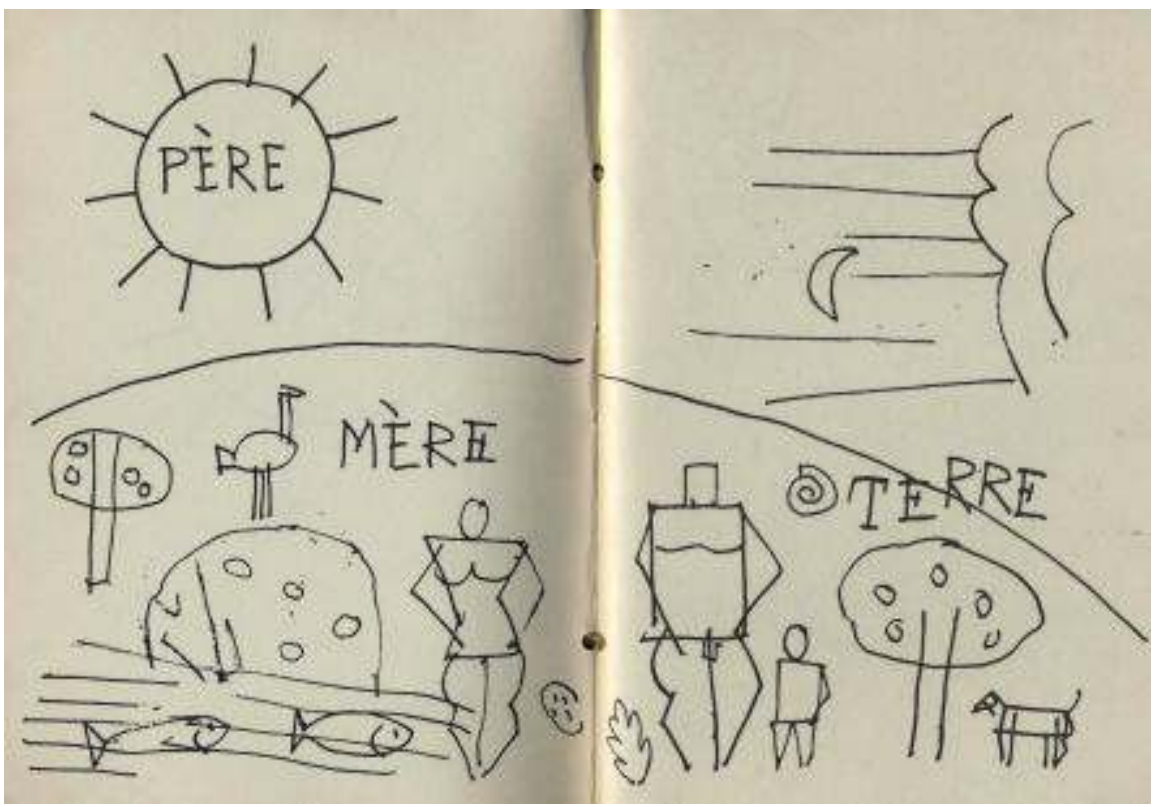

Esto es subrayado por el segundo grupo lexical (de "sentido" a "cosmos") donde el vocablo "sentido" (lo que da significado) está adjunto a la preposición "uní" también al interior de un dibujo del sol, anexando luego la palabra "universo". Se remarcan también en éste conjunto "equilibrio" y "unidad" "sistema planetario" y finalmente "Kosmos".

Figura 3 - Segundo grupo lexical (en Torres-García, Joaquín : 1931).

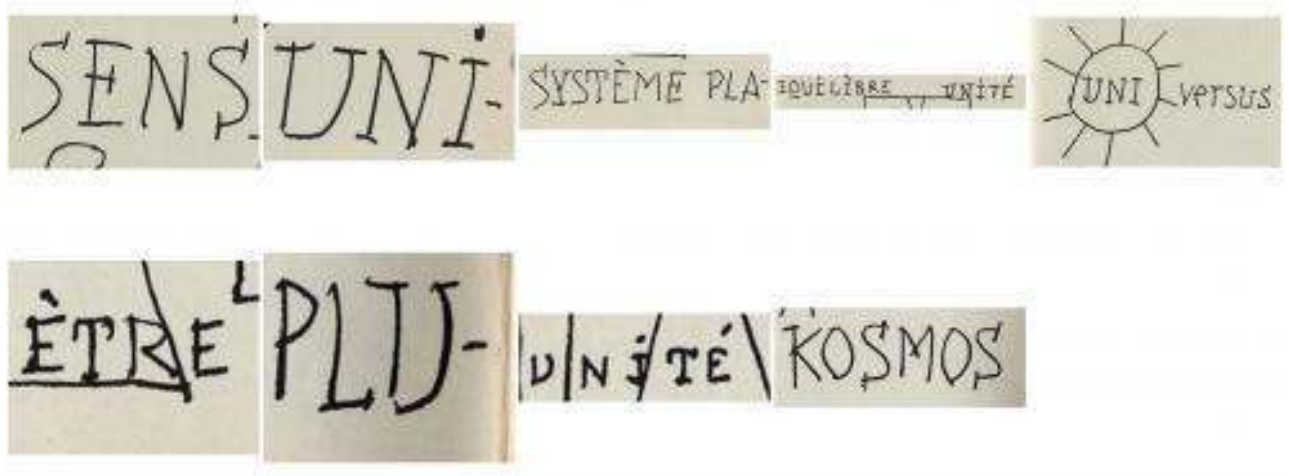

Aquí el termino "equilibrio" junto a "unidad" tratan del funcionamiento del sistema planetario. Este grupo semántico refuerza la estrategia de generalización que para el caso de Torres-García bien se podría llamar "kósmica" en tanto sobre lo concreto el pintor uruguayo ve lo general. Sirva como ejemplo de lo polisémico de esta generalización la referencia al "sol", antes relacionado con el padre y ahora con la unidad (del universo, de 
lo más alto, pero luego lo veremos también del ser humano y del Cristo, de lo eterno y finalmente de la unidad de la obra creativa).

Figura 4 - Diferentes representaciones gráficas del sol tomadas de PÈRE SOLEIL (en Torres-García, Joaquín: 1931).

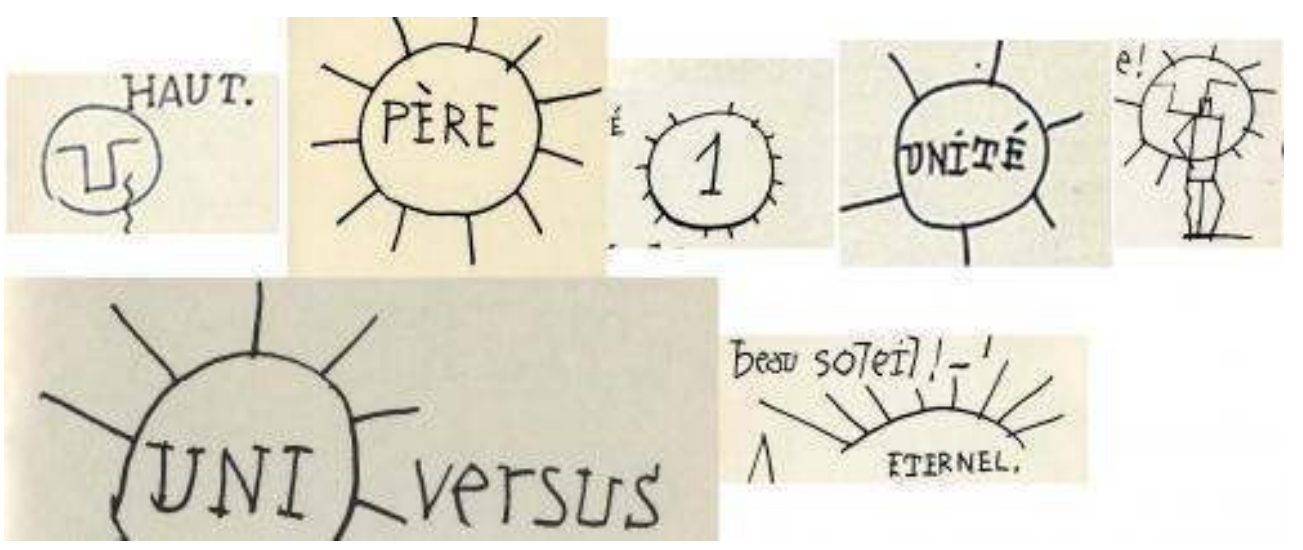

Sistema planetario que será también tratado en el tercer grupo lexical donde sólo una parte de la palabra "planetario" (netario) es visible con términos como "ley" "unidad" "ser" "pluralismo" "todos los ojos conforman un ojo". En este grupo, las expresiones en mayúsculas están acompañadas de figuras humanas. Quizás para descender de lo cósmico a la comunidad humana (dibujos de hombre y mujer y geométricos las acompañan) y no al sistema planetario dibujado arriba.

Figura 5 - Tercer grupo lexical (en Torres-García, Joaquín: 1931).
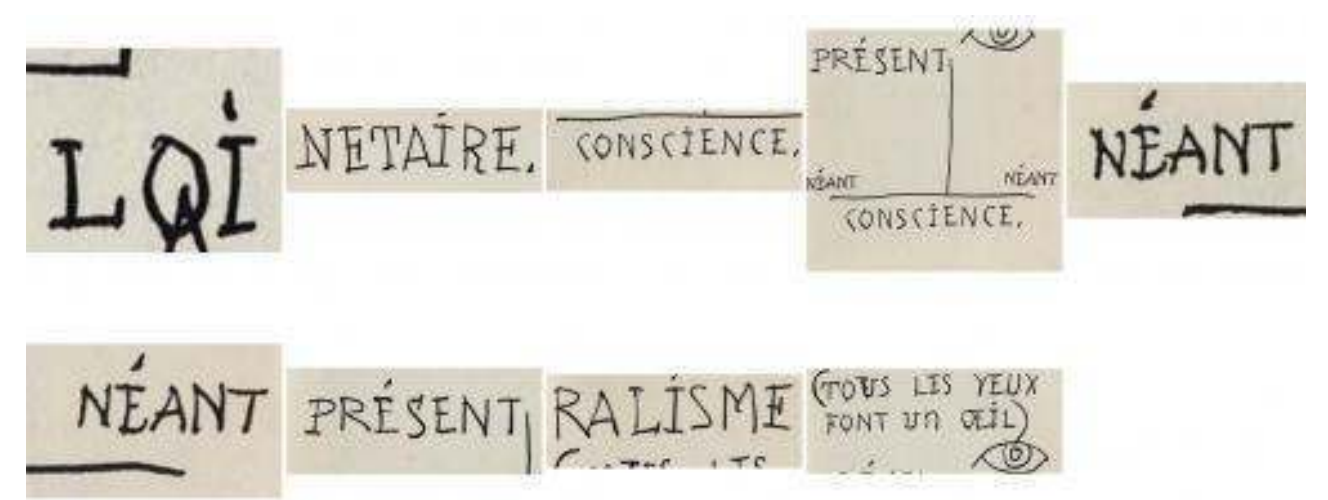

El vocablo "pluralismo" seguido de la frase "todos los ojos hacen un ojo" muestra el carácter decididamente dialéctico de la ley y de la unidad, concebible hasta en la concepción de la percepción óptica del mundo con sus diferencias y variedades deseada por el autor. Esta dialéctica entre pluralismo y unidad culmina entonces en un recorrido que comienza con la ley unitaria del hombre (o "ser") se amplifica en el pluralismo para terminar en un misterioso ojo único. 
Figura 6: “Presente”, “Nada”, “Conciencia” (en Torres-García, Joaquín: 1931).

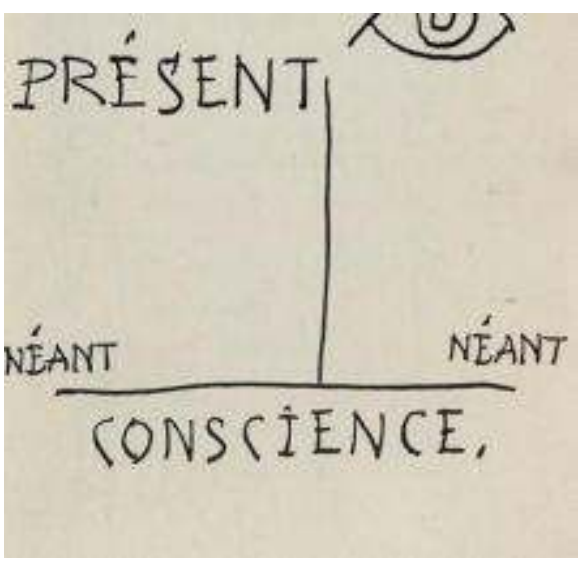

17 La estructura (más que grupo semántico) aquí representada, está conformada por la palabra "presente" unida por un trazo vertical a la "conciencia", colocada abajo de una línea horizontal que une dos términos separados por la línea vertical : "nada" o "vacío". Este término no deja de plantear muchos problemas interpretativos (las posibles respuesta à estas incógnitas se intentan en el próximo capítulo) pero en todo caso la ilustración parece conformar un esquema de la actividad cognitiva, donde el ojo tiene como manifestación la palabra "presente" y está ligado a la conciencia por una línea vertical. A los lados izquierdo y derecho, el vacío.

Figura 7 - Cuarto grupo lexical (en Torres-García, Joaquín: 1931).

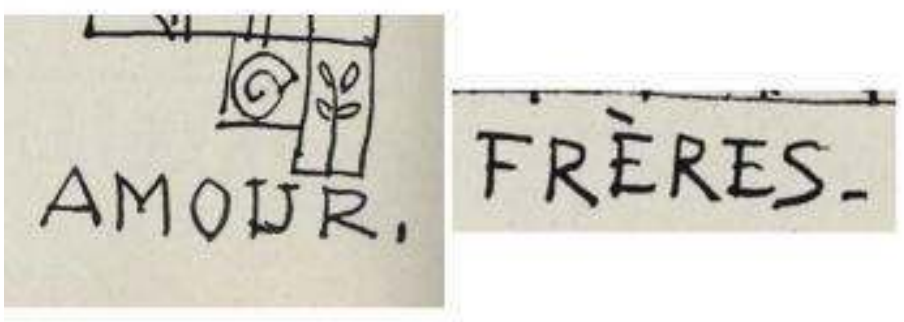

'Hermanos" (frères) y "Amor" el cuarto grupo está acompañado de la cifra 1 y rodeado de un dibujo donde siete humanos iguales y pegados unos a los otros tienen sobrepuesta una figura un poco más alta aureolada de sol. La imagen entonces plantea de nuevo la temática de la unidad (de allí la cifra) pero esta vez en el mundo humano. 
Figura 8: Ilustración izquierda tomada de "Freres" de Torres-García (en Torres-García, Joaquín : 1931) y derecha “El rayo de luz » (Monlaur : 1916).
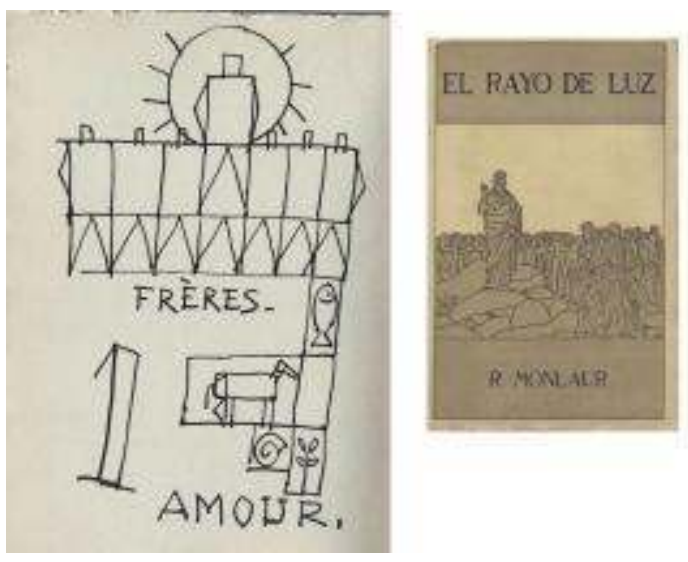

Llama la atención por su parecido con la ilustración que Torres-García realizó para el libro "El rayo de luz" (editado en España en 1916), en donde sobre un grupo humano se destaca el Cristo, permitiendo de inferir que la comunidad artística de hermanos deseada por el pintor, toma modelo de la primera comunidad cristiana dibujada de la misma manera en el libro de R.Monlaur.

La multiplicidad de la naturaleza significada por las ilustraciones de los animales y las plantas que descienden hasta la palabra "amor", indican que éste (en la parte inferior del cosmos) es la simiente o el motor fusional de la unidad significada por el sol en lo alto.

Figura 9 - Quinto grupo lexical (en Torres-García, Joaquín : 1931).

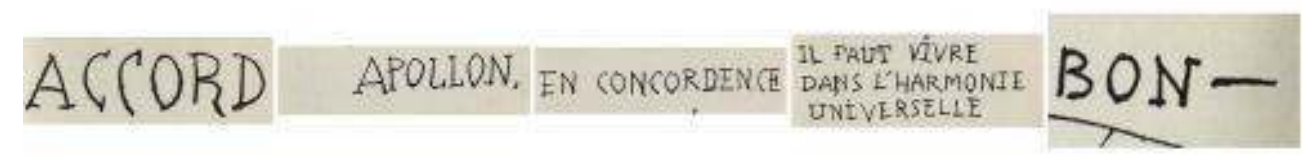

\section{DISCORDANCE: HARMONIE :}

La quinta agrupación lexical vuelve a la temática del funcionamiento del Universo de carácter musical, donde el "acuerdo" o el "acorde" (en francés la misma palabra tiene los dos sentidos, el social y el musical) junto con la "harmonía universal" terminan la frase (toda en mayúscula) con la palabra "en concordancia" y un dibujo de la parte superior de un reloj, con la aguja entre el número 3 y el 4. La introducción repentina del nombre del dios griego Apolo, dios identificado al sol en la mitología griega y conductor de las musas, sobretodo de la poesía y de la música, posiciona entonces claramente Torres-García en el marco estético del clasicismo griego. Esto es subrayado en los términos de la página siguiente ("Harmonía", "Bueno", "Discordancia") en donde Torres-García hace variaciones sobre el sentido etimológico de la palabra "armonía" derivada del griego

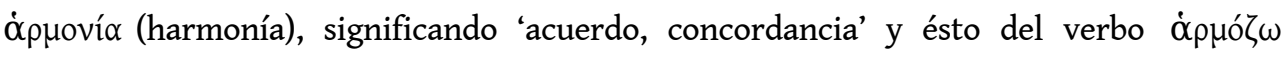
(harmozo): "ajustarse, conectarse". ${ }^{2}$ 


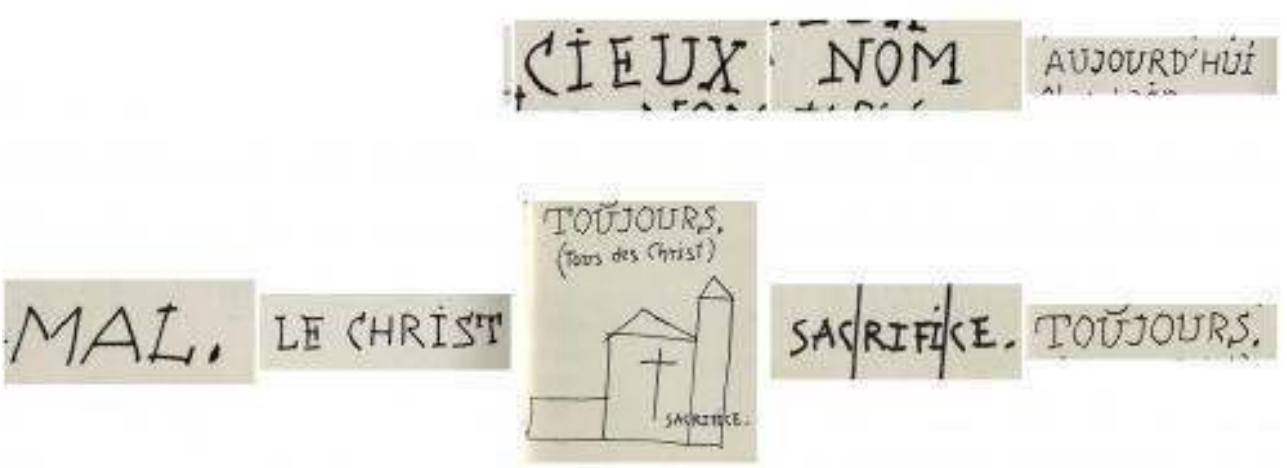

El conjunto mostrado aquí arriba, está por el ritmo y el estilo de la frase, ligado al mundo religioso católico (la figura de la iglesia y la repetición del nombre de Cristo argumentan en éste sentido) y está conformando un mismo grupo de 6 páginas. "Hoy" y "mal", así como "Cristo", "siempre" y "sacrificio". Así, al "Padre" de ésta plegaria, dibujado como un sol, idénticamente presente en el cielo que el Dios hebreo, se le solicita proveer "hoy" la ayuda y la comida. La urgencia del pedido, al cual sigue la palabra "mal" termina en otra imagen del sol, esta vez con el Cristo a su interior.

Figura 11 - "El Cristo" con un sol rodeándole la cabeza e inserto al interior de una cruz englobada por un gran sol. (Torres-García, Joaquín : 1931).

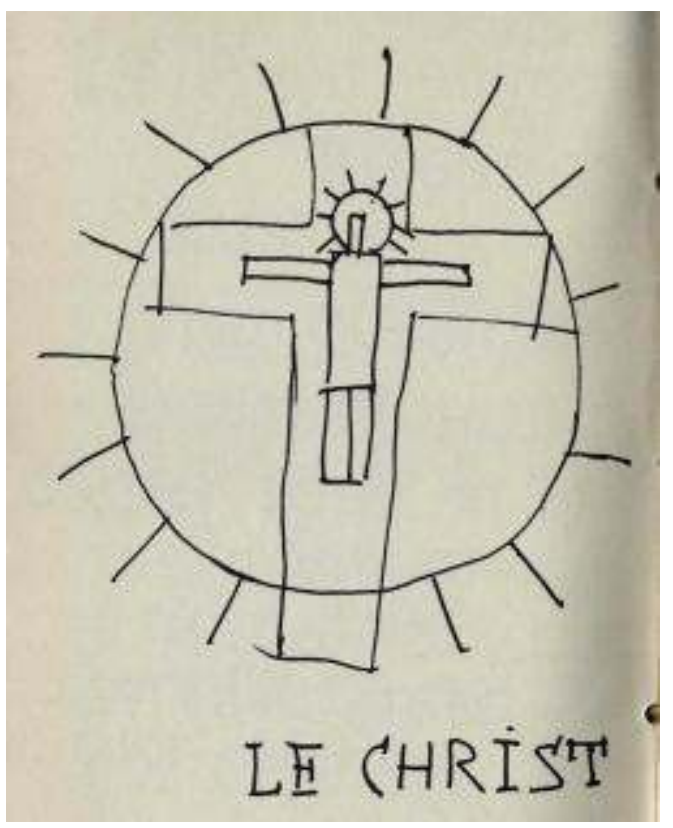

Este Cristo parece una variación de imágenes bastantes conocidas de la cruz al interior de una rosa (ver figura 16 aquí abajo) por ejemplo, propias a las logias rosa-cruces. Llama la atención el isomorfismo de las figuras del Cristo y del pequeño sol con la cruz y el sol englobando todo el dibujo. 
Figura 12 - Séptimo grupo lexical (en Torres-García, Joaquín : 1931).
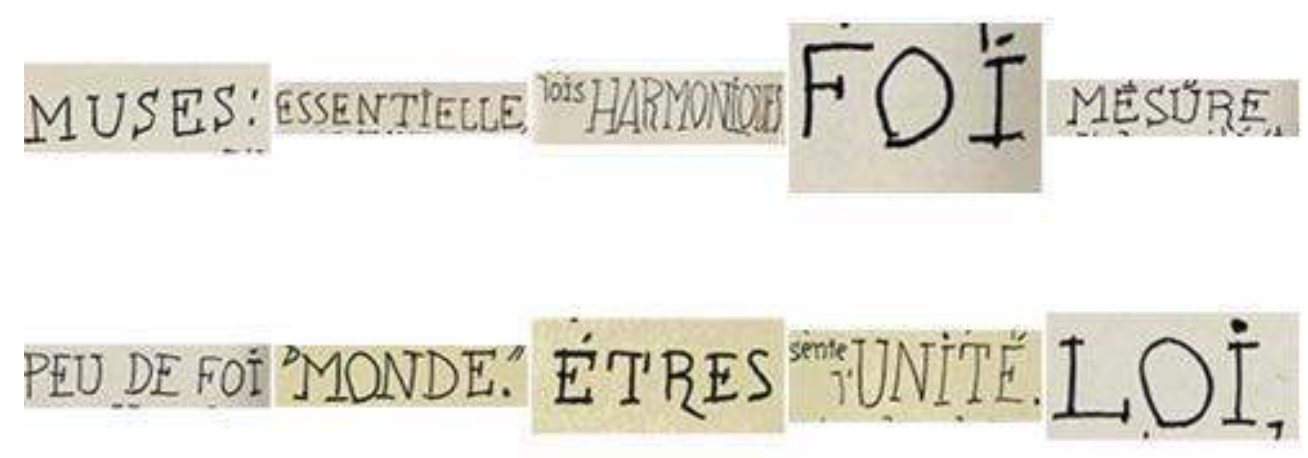

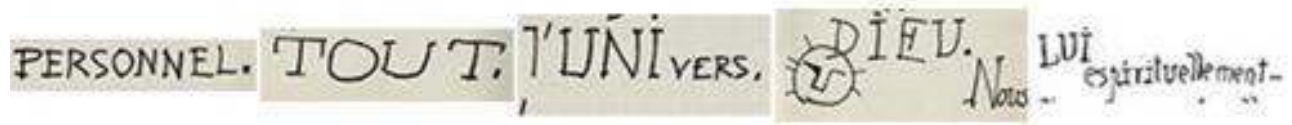

El próximo grupo comenzando con "Musas" vuelve al universo griego con referencias a Pitágoras de Samos y a Safo, así que con términos como "medida", "poca fé" y "fé", "esencial”, "harmónicas”, “mundo" y "unidad”, "seres”, “personal”, “ley”, "universo” y "todo". "Foi", la fé, está repetida dos veces en esta hoja y a la que vuelve poco más tarde, con un diseño que ocupa casi la mitad de una página. La armonía está fundamentada en la fé, sirviendo de sostén a la unidad, conformando la totalidad o al menos el universo de los seres esenciales.

Figura 13 - Octavo grupo lexical (en Torres-García, Joaquín: 1931).

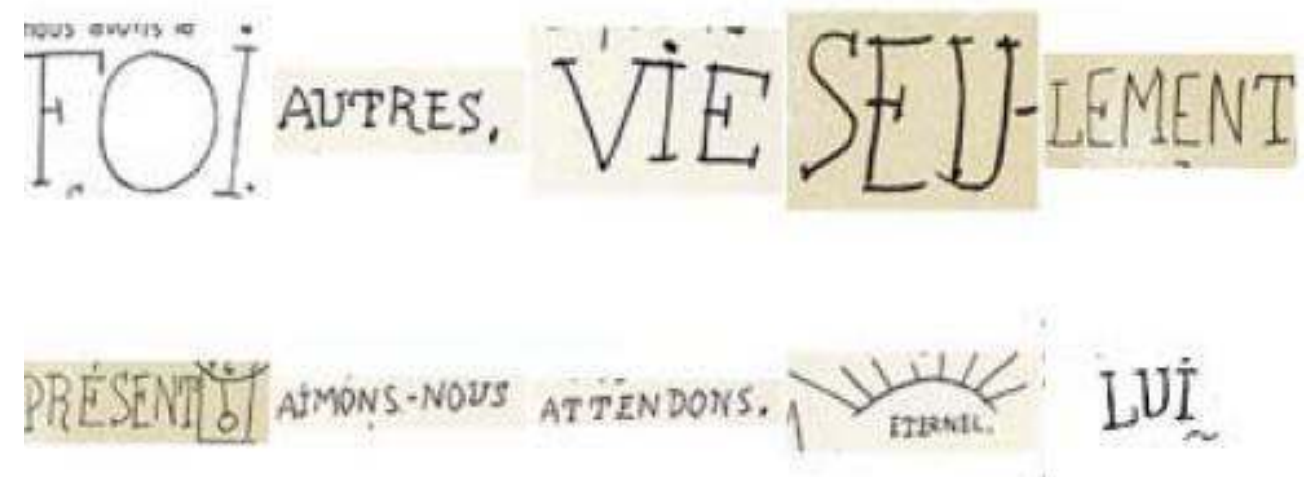

La fé, entonces (la palabra con grafismo más grande de todas las palabras seleccionadas) hace también parte del grupo lexical octavo. Dios es representado una vez más (por segunda vez) como un sol antropomórfico, sobrepuesta al cual se encuentra la frase : "Nuestro Padre que está en los cielos". 
Figura 14 - Página haciendo parte del octavo grupo lexical donde el sol está acompañado de la frase “Nuestro Padre que está en los cielos.".(en Torres-García, Joaquín : 1931).

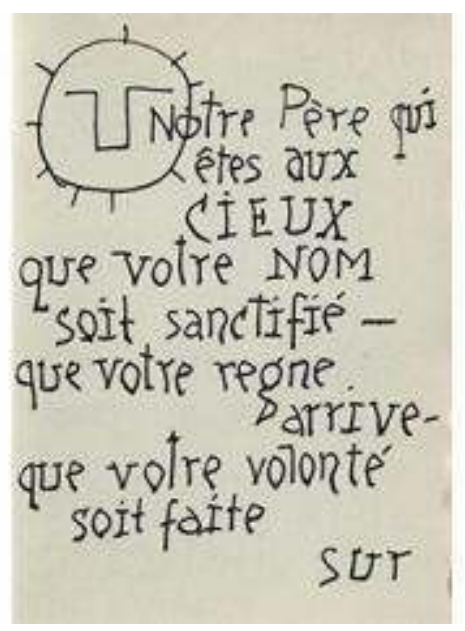

Pero otra variación del nombre de Dios, con el pronombre personal "EL" en mayúsculas (LUI), muestra el vaivén del autor entre temas griegos y cristianos. La "vida", y la importancia "solamente" del "presente", pese a los "otros" (connotando nostalgia de otros tiempos diferentes a los actuales, donde imperan, si no hay fé : odio, desconfianza, celos y desesperanza) son temas que de nuevo el "amor" "eterno" (inserto éste último término en una imagen de sol naciente) subsana.

Figura 15 - Noveno grupo lexical (en Torres-García, Joaquín : 1931).

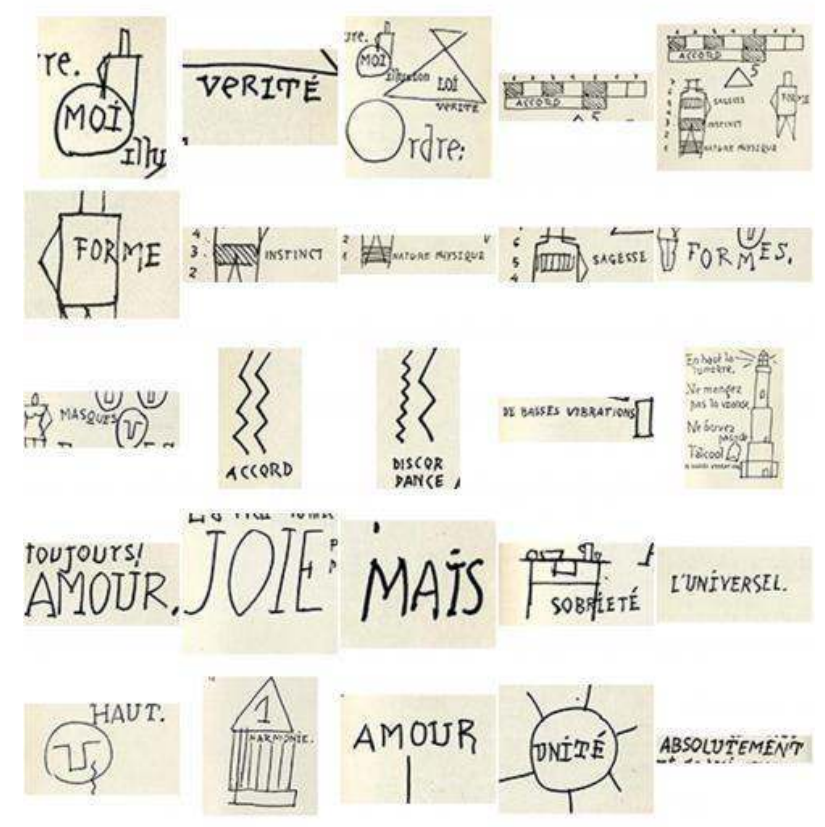

En el noveno grupo lexical, el campo semántico abordado va del mundo cristiano al esotérico ahora, en particular para estudiar el mundo de la Naturaleza. En éste, el 5 y el 7 son las cifras o las escalas de la existencia. Tanto la armonía de la forma como la 
composición del ser humano están relacionadas con estos números, donde siete partes están marcadas físicamente sobre el cuerpo y tres aspectos de la vida son detallados : la "sabiduría", el "instinto" y la "naturaleza física". Es en éste grupo que finaliza el libro, donde encontramos temas desarrollados por la teosofía, tales como la importancia de la numerología ya mencionada, las "vibraciones" (en forma de "acuerdos" y "desacuerdos" dibujados en tanto que ondas vibratorias), la importancia de la higiene alimentaria con términos como "sobriedad" o en minúsculas en este caso de la abstinencia (evitar la "alegría de la botella", con dibujo) y de términos como la magia blanca y negra. Allí, en ese conjunto semántico aparece el termino "universal". Otros temas importantes son la palabra "alto" como los repetidos, "armonía", "amor" y "unidad", que son también términos muy usados en el corpus teosófico.

\section{Del cristianismo a la teosofía}

Las relaciones de Torres-García con los grupos católicos han sido muy importantes en la primera juventud del pintor. A partir de los 19 años, sin olvidar las posibles inclinaciones religiosas familiares, estuvo muy relacionado con el Círculo Artístico de Sant Lluc. ${ }^{3}$

De esto son testimonio los libros ilustrados realizados en colaboración con intelectuales de tendencia católica. Solo que a la lectura atenta de "Père Soleil" esto no se limita a su primer período. Bien que como lo remarca Juan Flo "su catolicismo juvenil es un hecho que él evitó mencionar pero que creo que se puede conjeturar sobre buenas bases", analizando las imágenes de su trabajo de los años treinta (en esa época el pintor contaba con 57 años) no se puede despreciar la importancia de las ideas cristianas y de la omnipresencia, en la obra estudiada, de la imagen del Cristo. Esta es una de las tradiciones mas importantes que nutren su obra y lo muestra en el texto arriba estudiado, repetidas veces, del Cristo con un sol rodeándole la cabeza e inserto al interior de una cruz englobada por un gran sol.

La segunda tradición que parece incontestable es la filosofía y la cultura griega. El tema ya ha sido bien analizado en su período barcelonés, donde Torres-García con osadía (no hay que olvidar que se lo conocía como emigrado uruguayo, llegando a Barcelona a los 17 años) amplía la cultura mediterránea del noucentisme en su plástica, con los aportes del clasicismo griego (Bastos Kern, 1997: 124). El análisis de los primeros grupos lexicales nos permite de conjeturar que Torres realiza una sabia mezcla de estas dos tradiciones, con una reflexión sobre la unidad y la pluralidad. Pero tanto los filósofos y artistas citados (Pitágoras, Safo) como ciertos términos tirados de esta tradición ("Medida", "Harmonía", "Musas", etc..) muestran la relevancia en su obra de ésta corriente intelectual. 


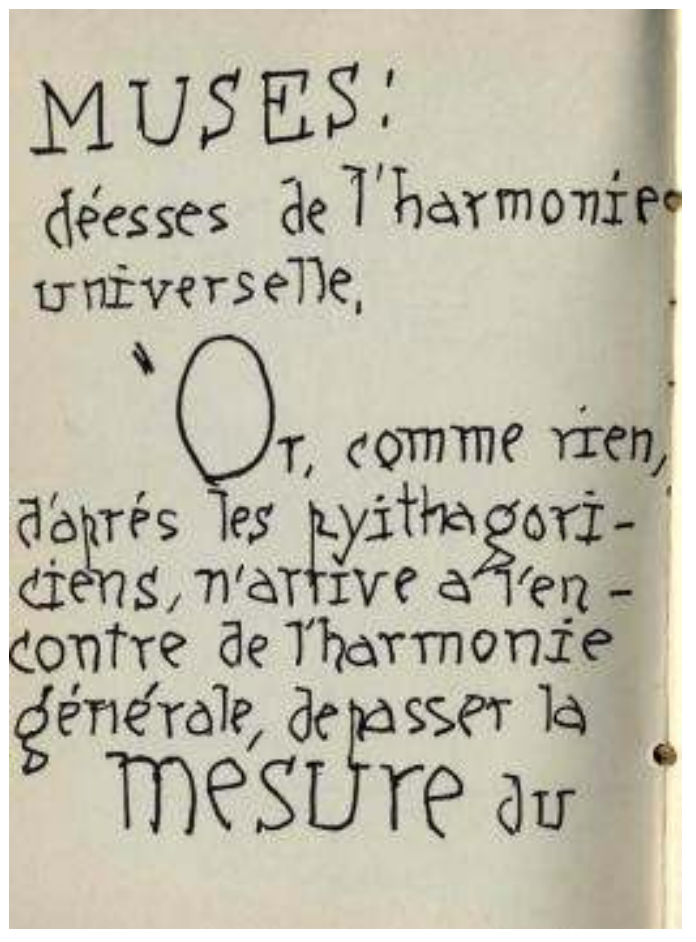

El último grupo lexical sin embargo, así que la imagen del Cristo mostrada más arriba, nos plantean ciertas interrogantes. Una de las estrategias plásticas aplicadas por nuestro pintor con la imagen de Cristo, es de remplazar la imagen de la rosa, propia a los rosacruces por la del sol. Es conocido que los Rosa-Cruces son una orden hermética cristiana cuya primera mención se remonta a principios del siglo XVII en Alemania. Una de las imágenes más características de estos grupos, es una rosa envolviendo la cruz, como en esta imagen donde se encuentra una cruz y una figura humana rodeados de una rosa y un sol haciendo parte de las "Figuras secreta de los Rosacruces", hallados en Altona cerca de Hamburgo.

Figura 16 - A la derecha una imagen haciendo parte de las "Figuras secreta de los Rosacruces", impresos en dos partes en 1785 y luego en 1788 en Altona cerca de Hamburgo. Incluyen entre otros 36 grupos de imágenes y símbolos alquímicos, teosóficos y herméticos. El autor es desconocido. A la izquierda el Cristo de Torres-García (Torres-García, Joaquín: 1931).
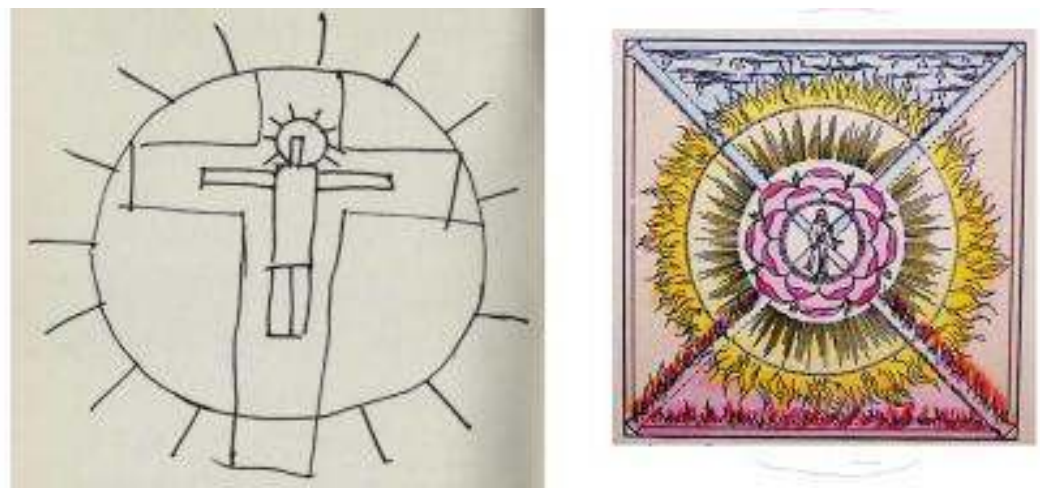

En el cuadro arriba descripto tenemos esta representación de los rosacruces, al lado de la cruz de Torres-García, la cual agrega un interesante juego de correspondencia entre la 
cabeza de Jesús rodeada del astro rey y éste envolviendo la cruz. En la figura del siglo XVIII se incluye una rosa al interior del sol.

\section{Comparativo del léxico de Torres-García y del corpus teosófico}

Marie-Aline Prat es la primera a afirmar que las relaciones de Torrès-Garcia con el esoterismo son indudables. Según esta autora, las referencias frecuentes a las "buenas vibraciones" del pintor constructivista (de las cuales hemos visto algunos ejemplos en el capitulo anterior) parecen corresponder al concepto de "thought-wave" de los discípulos de M.Blavatsky. Por otra parte ella encuentra, en la simbólica que elabora el pintor, varios de las figuras esotéricas de la antroposofía popularizadas por la obra de Saint-Yves d'Alveydre, en particular "L'archéomètre, clef de toutes les religions" (Prat, 1984 : 138).

Prat menciona el tema en una nota al pie sin desarrollarlo. Sin embargo la conjetura es interesante y merece ser estudiada más en profundidad.

En efecto, solamente en la definición del término Archéomètre encontramos muchos de los temas tratados en "Père Soleil" y que Torres-García considera emblemáticos en su "constructivismo". Por ejemplo, según d'Alveydre la palabra "Archéomètre" proviene de dos palabras en sánscrito védico "ARKA" y "METRA". ARKA, es decir el Sol, es el emblema central del Sello Divino. "El circulo está armado con sus rayos, rueda radiante de la Palabra divina" (Saint-Yves d'Alveydre, 1910: 104). Dice que el neologismo también significa la unión primordial del Espíritu, del Alma, del Cuerpo y de la Verdad. ARKA significa también el poder de la manifestación de la Existencia, la celebración de la Palabra y "la revelación de los misterios del Hijo por la Palabra como Palabra Creadora" (Saint-Yves d'Alveydre, 1910 : 104).

MATRA es la medida pero también la Madre por excelencia. Vemos aquí la traslación del dualismo père/sol (Arka) y madre (Matra) también puesto por Torres-García al principio del libro que analizamos. En tanto que regla, también manifiesta la unidad y la universalidad de la distribución de sustancias en sus equivalentes orgánicos. En el nivel físico universal, también se interpreta como el amor femenino. Dice el autor : "MATRA es también el signo métrico de don divino, el de toda la sustancia proporcional y armónico" (Saint-Yves d'Alveydre, $1910: 105)$. 
Figura 17 - Cubierta del libro "Padre Sol”, respondiendo a la proporción áurea. Esta, también llamada "divina proporción", surge de que el volumen más grande es proporcional al rectángulo medio como este lo es con el más pequeño. En la parte alta de la tapa, el nombre escrito a la manera catalana -Torrés-Garcia- precedido de la primera letra de su nombre y un punto. Al medio el sol antropomórfico. Abajo un rectángulo dividido en dos, a la izquierda el espacio del hombre con dibujos de animales (elefante, serpiente, caballo, pez) un árbol, una espiga de trigo y una estrella. A la derecha, el espacio de la mujer con su figura, un árbol un caracol y un barco de papel (arriba) y un pájaro y la pictografía de una casa (abajo) - (Torres-García, Joaquín: 1931).

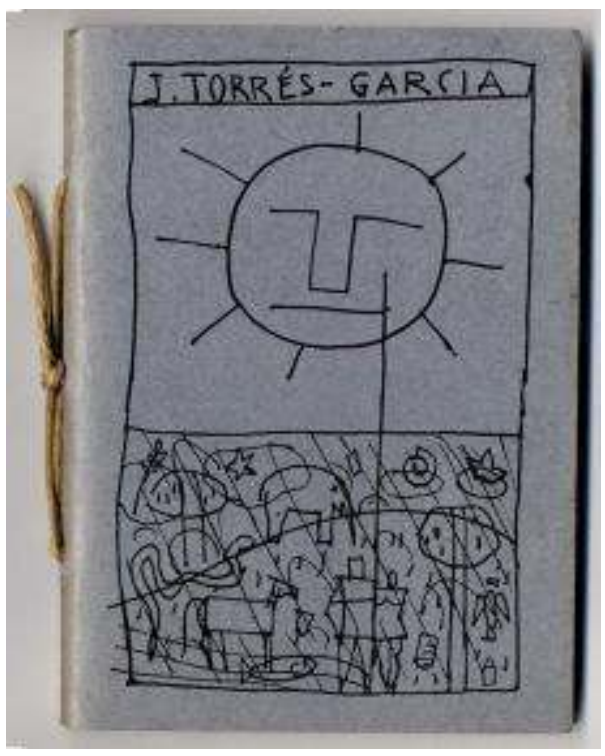

\section{desarrollados en "Père Soleil", como el hombre y la mujer universal representando la} estructura cósmica, el sol como palabra divina como manifestación y creación de las existencias y del bienestar del universo. Pero también la temática de la unión a través de una misma medida y de las proporciones universales, en resumidas cuentas la harmonía, tal que fué concebida por los pitagóricos. Porque como lo afirma el legendario hermetista Papus:

'Si el hombre comprende, adapta entonces sus leyes personales a las del Padre, y así el Reino del Padre se realiza. El conocimiento de este reino, incluye todas las leyes de la armonía en todos sus planos" (Papus , $1918: 81$ ).

Figura 18 - "Kosmos” (en Torres-García, Joaquín : 1931).

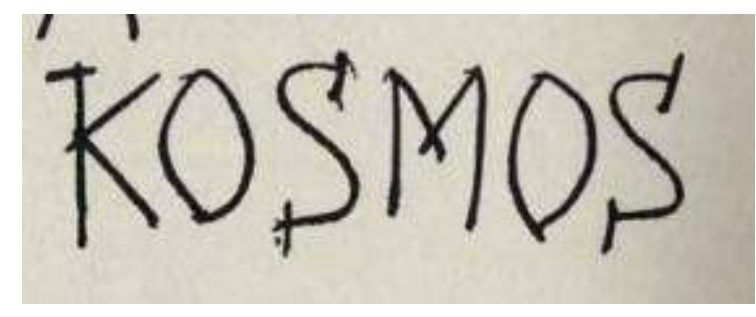

Pero también en el texto "L'évolution divine : du sphinx au Christ" de Edouard Schuré encontramos la palabra "Kosmos" como Torres-García la escribe en su forma etimológica griega. Dice Schuré que en el Kosmos reside el espíritu creador y citando Kepler asegura que "Toda la creación constituye una sinfonía maravillosa...todo se tiene y se sigue con relaciones mutuas indisolubles y todo conforma un conjunto armonioso. De esta manera lo que existe y está vivo y vibrante, se vincula. El movimiento de los astros se explica por 
esta simpatía mutua que los une y que explica la regularidad de los fenómenos naturales"« (Schuré, 1912: 9).

De la misma manera R.Steiner afirma que es necesario venerar esta totalidad, esta Harmonía y esta Unidad del mundo (Steiner, $1923: 146$ ).

Y volviendo a la metáfora musical Annie Besant, sostiene que como un músico escucha el desacorde (discordance) musical en una melodía, se puede en la vida diferenciar la verdad de la mentira (Besant, 1912: 165).

Figura 19 - “Presente” (en Torres-García, Joaquín: 1931).

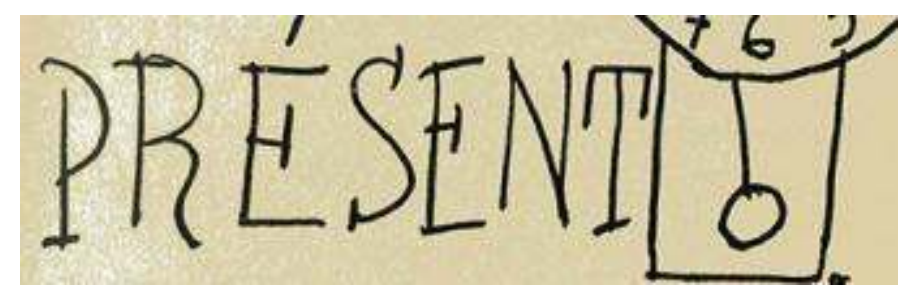

El concepto "presente" en Torres-García esta posiblemente ligado a la idea planteada por E. Schuré (1912: 276 ) en el cual el Dios al cual los griegos rendían pleitesía, el dios sol "que trajeron -los helenos- en sus ojos azules, en sus aljabas resplandecientes y en sus himnos, no era un Dios lejano, sino un Dios presente en todas partes donde brillaban sus rayos".

Pero también el diseño de la cabeza de Cristo aureolada con un sol pequeño al interior de una cruz (isomorfa al cuerpo de Cristo) y englobados todos estos elementos con un sol, que hemos visto más arriba, plantea una visión compleja que puede explicarse con esta frase de unos de los creadores de la Asociación Teosófica Francesa : "Más la conciencia se expande, más cerca estamos de un eterno presente, más los planos anteriores y futuros de la existencia tienden a fusionarse en el eterno presente" (Revel, $1913: 110)$. Porque todos podemos brillar como "un centro luminoso intelectual, moral, y físico" (Revel, 1913: 149).

Asi G. Revel aconseja dejar vibrar en nosotros el mundo superior. Dicha veneración solar se basaba en un análisis de "la religión de los peruanos". La civilización incaica, según Revel, rendía culto al sol, no al astro físico sino al Espíritu del Sol, aquel que para ellos era la Suprema Esencia. El hecho más sobresaliente de esta religión, para el autor francés, era la alegría (joie). Ella debía iluminar todas las personas, no una alegría fingida o hipócrita, sino una verdadera felicidad (Revel, 1912: 240). Esta conciencia fusionando pasado y porvenir en un eterno presente, en el corpus teosófico estudiado, significa también la conciencia del espíritu divino o del deber moral.

Pero volviendo al dibujo del uruguayo, el "presente" está articulado a la palabra "consciencia" y rodeados de la repetición del término "nada" o "vacío". 


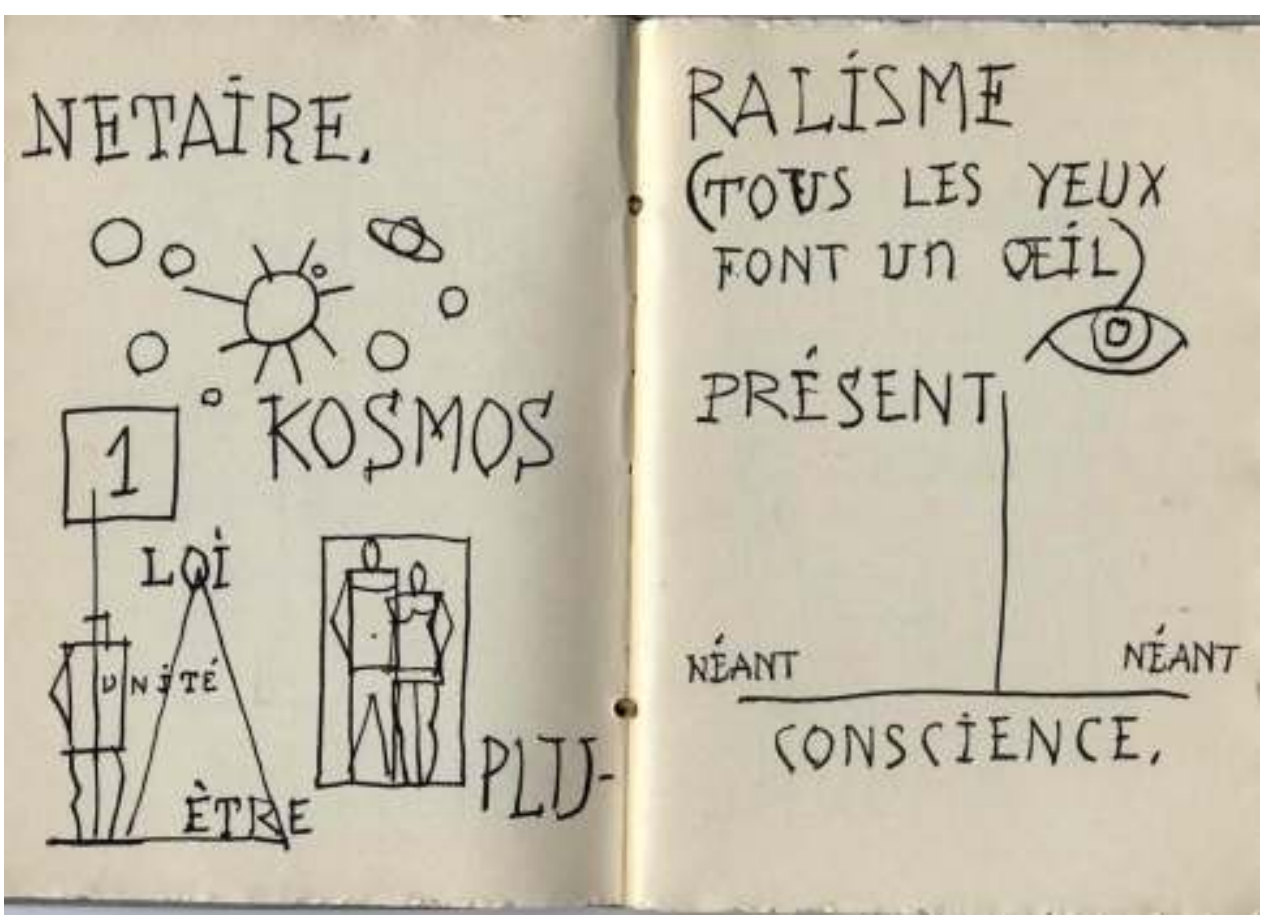

En un artículo reciente (Vidal, 2014) hemos mostrado la importancia para la creación de "Père Soleil" del libro "La magie blanche et noire, ou la science de la vie terrestre et de la vie infinie contenant des conseils pratiques pour les étudiants de l'occultisme" de F.Hartmann. Este médico ocultista, que también ha sido uno de los pioneros de la homeopatía, asegura que "si tal conciencia no existe, si no había nada en (el ser humano) para hacerle sentir su propia naturaleza divina (...) él se quedaría solo con la nada (néant), con un espíritu vacío..." (Hartmann, 1903: 282). Es este tipo de reflexiones que pueden explicar porqué Torres-García, quien ha leído este libro hasta copiar fragmentos enteros, dibuja alrededor de las líneas perpendiculares el vacío (ver figura 20).

También Georges Chevrier en "La mission créatrice : plans, ego, réincarnation" enseña con una metáfora que sí, un ciego no ve la luz, no quiere decir que ésta no exista. Si sus ojos no le permiten percibir la realidad, al menos el ciego no generaliza su estado al mundo. Del mismo modo, si en este mundo materialista, muchos han cerrado sus aparatos perceptivos espirituales y morales, no quiere decir que el mundo moral o espiritual no exista (Chevrier, 1917: 110).

Estas reflexiones tal vez puedan explicar el dibujo del ojo de la ilustración de más arriba y la frase "pluralismo (todos los ojos hacen un ojo)", inmediatamente anterior. En efecto, rodeadas de las expresiones "conciencia" y "presente", este dibujo trata sin duda de la percepción y de la conciencia alrededor de las cuales flota el vacío.

Lo que G. Chevrier llama "una capacidad de percepción diferenciada" está también ligado a los diversos planos de conciencia, propios a la temática de las manifestaciones de la forma en la doctrina Teosófica. Así en la imagen de las líneas perpendiculares donde la conciencia se une con el presente, parece evocar una geometría espiritual básica también descripta por G. Chevrier, según la cual el punto, la recta y el plano, son elementos de diferentes grados de conciencia. Cada una de estas formas es el substrato de un 
movimiento vibratorio, constituyendo así la base de manifestación de un estado de conciencia. Y el resultado de esta manifestación se expresa a su vez en una forma de vida (Chevrier, 1917: 24).

Figura 21 - "Vibraciones”, “acordes” y “desacordes” (en Torres-García, Joaquín: 1931).

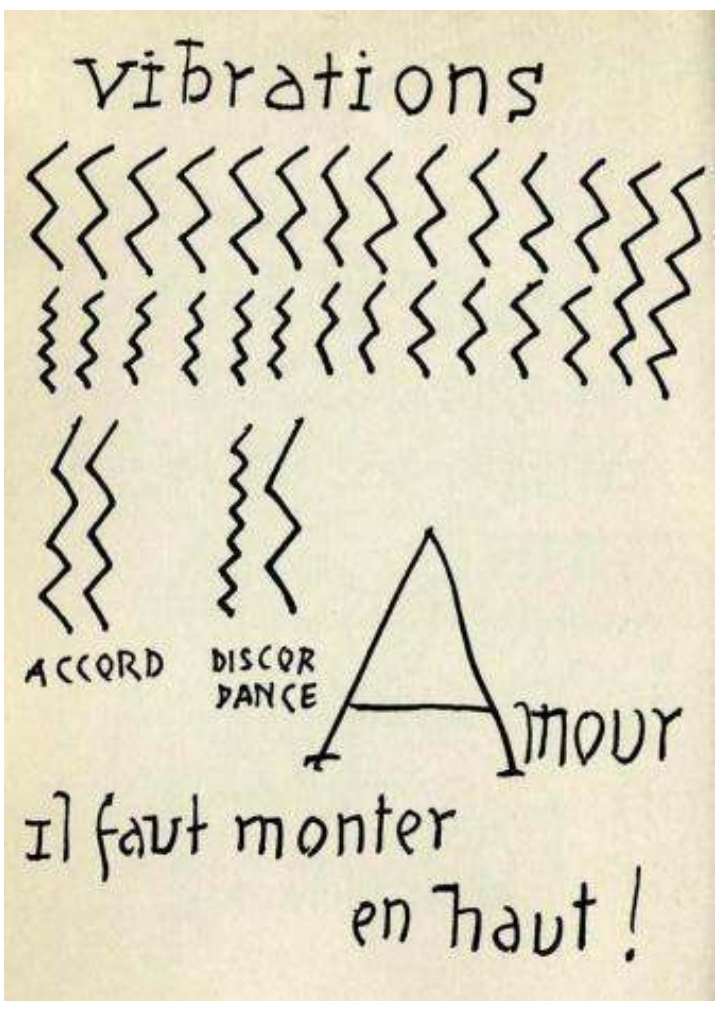

En el ejemplo de Chevrier, la conciencia está determinada a su vez por la vibración del punto, capaz de conformar con su movimiento una gran cantidad de líneas. Pero si la línea es una vibración (como movimiento y multiplicación) del punto, la vibración de la recta creara el plano (Chevrier, 1917: 20-23). De este modo, la percepción de la vibración de cada forma (punto línea plano) depende entonces del estado de conciencia. Las dimensiones de la conciencia varían, en razón inversa de las dimensiones de la forma y cada una de éstas tienen su vibración diferente. Como diferente será el movimiento del punto para conformar la línea y de ésta para formar el plano. En el ejemplo geométrico del ingeniero Chevrier, el estado de conciencia simbolizado por la línea recta no percibe el punto, y el estado superior simbolizado por el plano no percibe ni la línea recta ni el punto. Así, siguiendo este ejemplo, G. Chevrier propone el $\mathrm{Ego}^{4}$ como una evolución, comparado con el estado animal. Pero de acuerdo a como éste se identifica con los diferentes estados vibratorios a su disposición (más o menos groseros), limita de la misma manera sus estados de conciencia. Notamos sin duda, que la teosofía de ésta época estaba muy marcada por el pensamiento hindú. Así se explica la reflexión sobre el movimiento (ligado al estado vibratorio) y la afirmación de que la liberación del Yo pasa por la quietud, por la substracción de esta pulsación vital, del movimiento constante propio al ser humano. La vorágine de la inquieta condición humana no le permite percibir plenamente las cosas de éste y de otros mundos. Por lo tanto, si deja de seguir el movimiento de la línea, se puede percibir el volumen y así sucesivamente cada movimiento abandonado abre un nuevo mundo y, cada nuevo mundo, revela una dimensión desconocida (Chevrier, 1917: 28). 
Para el autor finalmente la evolución espiritual se desarrolla a través de siete canales que hacen parte de tres estados, "uno donde el Espíritu desciende, otro donde Espíritu y materia están entrelazados, interpenetrandose con un sinnúmero de relaciones, finalmente un tercer nivel ascendiente donde todo entra en el Logos planetario" (Chevrier, $1917:$ 57).

Figura 22 - Las 7 partes del cuerpo y los tres niveles relacionados a la naturaleza física, al instinto y la sabiduría tomados de (Torres-García, Joaquín: 1931).

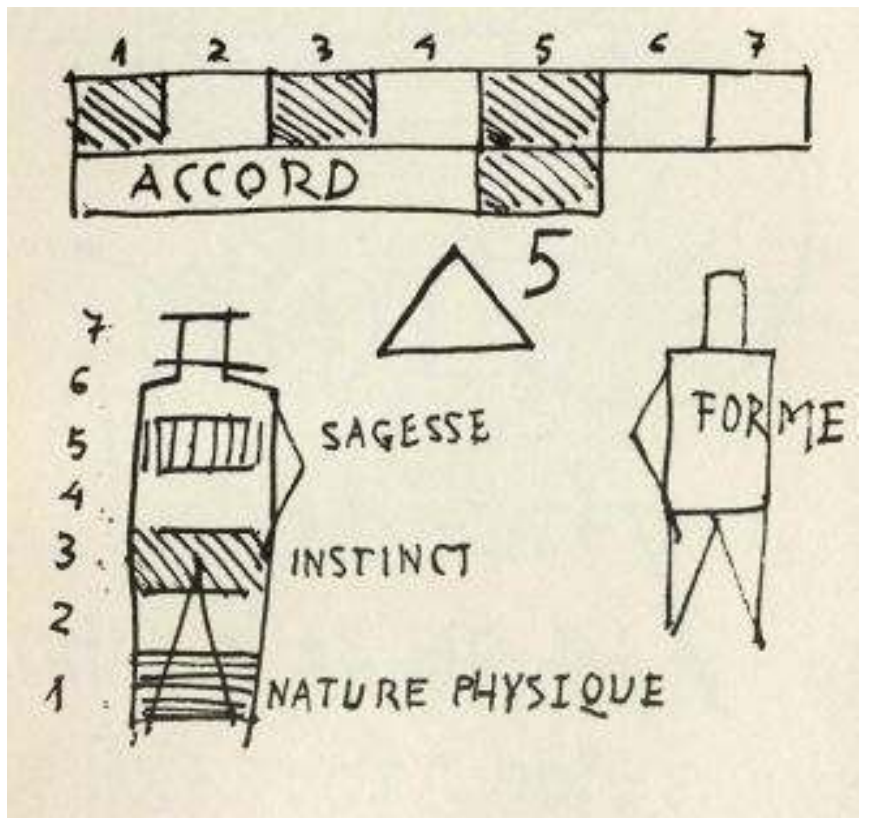

Esta dinámica ascendiente propia a la representación religiosa del cuerpo humano, la veremos también relacionada con las vibraciones que pueden ser altas y bajas. Vemos en la figura siguiente de nuestro pintor, donde lo alto corresponde a la luz de un faro y lo bajo a las vibraciones propias al alcoholismo. 
Figura 23 - Bajas y altas vibraciones ligadas al consumo de alcohol y a la consigna "No coman carne" tomados de (Torres-García, Joaquín: 1931).

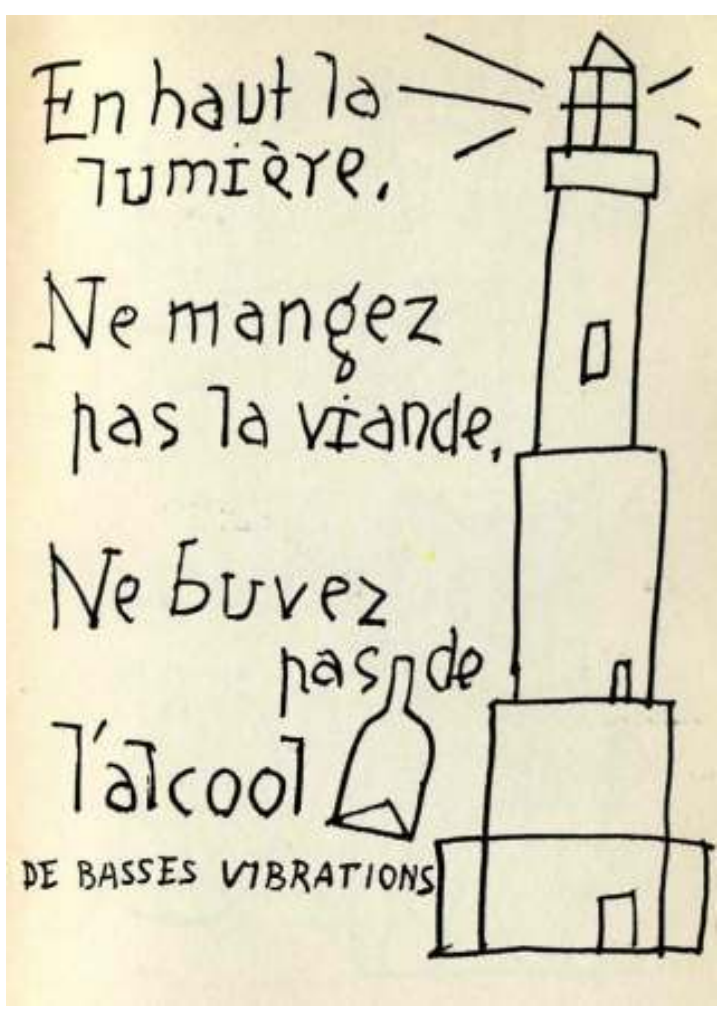

Terminaremos éste análisis de las relaciones entre el pensamiento de Torres-García con el corpus teosófico de principios del siglo XX, deteniéndonos en esta idea de lo alto y lo bajo, correspondiendo a una cierta representación de la materia y del espíritu. Como lo vemos en la figura 23, ella está también ligada a una representación del cuidado que el ser humano debe tener sobre su higiene de vida ("no coman carne", "no beban alcohol").

También F. Hartmann, en su libro sobre "La magie blanche et noire...", afirma que no es sin razón que el adepto a la magia blanca debe abstenerse de beber alcohol y de cualquier alimento carnal. Según este escritor, lo que puede ser bueno y comestible para una persona, puede envenenar a otra. Esto, en el ámbito de la materia, así como en la esfera de las emociones. No es que sea necesario -apunta el homeópata alemán- poseer una dietética vegetariana, para ser un buen adepto. Pero es preferible, sin duda, una dieta sin carne, por diversas razones entre las cuales la más importante quizás sea, de que tal dieta es absolutamente contraria, a la ley divina de justicia, que el prosélito pretende propagar. “Cómo alguien que se esfuerza por lograr un estado superior de existencia, puede quitar la vida a los animales o empujar a otros a hacer lo mismo?" (Hartmann, 1903: 196).

\section{Conclusión}

Al cabo de este recorrido por el léxico expresado por Torres-García en su libro "Père Soleil" y del análisis de la red de relaciones con el pensamiento ocultista francés, podemos concluir que son significativas las referencias a este corpus en el libro estudiado. En efecto, el movimiento creado por Mme.Blavatsky, pretendiendo ser una religión universal, había incorporado muchos de los elementos ideológicos del cristianismo tanto 
como del clasicismo griego. Este es un punto común con Torres-García quien también se propondrá el universalismo en su obra disponiendo para ello, tanto de una imaginería griega como cristiana. Desde un punto de vista de nuestra comparación de documentos, hemos notado que Pitágoras y el pitagorismo, por ejemplo, figuran como personaje principal de la mayoría de los autores de la asociación teosófica de París y lo encontramos también abundantemente citado por el pintor uruguayo.

Todo parece indicar entonces que Torres-García adiciona al primer estrato doctrinal cristiano (que sigue siendo importante en los años maduros para el autor) las referencias a los tratados ocultistas. Los indicios lexicales son abundantes (lo hemos indicado más arriba) y a veces, como lo hemos mostrado en otro artículo (Vidal, 2014), revelan de la copia pura y simple. En un estudio en curso sobre los libros ilustrados en su primer período español la imagen de la portada de "El rayo de luz" (Monlaur - Torres-García, 1916), nos mostrará sin duda la importancia de las referencias católicas, que están también presentes en el libro "Père Soleil".

\section{BIBLIOGRAFÍA}

BASTOS KERN Maria Lúcia, BULHõEs Maria Amélia, Universidade Federal do Rio Grande do Sul Editora, et Universidade Federal do Rio Grande do Sul Programa de Pós-Graduação em Artes Visuais, As questões do sagrado na arte contemporânea da América Latina, Universidade Federal do Rio Grande do Sul, Editora da Universidade, 1997.

BESANT Annie, L'avenir imminent / Annie Besant ; traduit de l'anglais

CHEVRIER Georges, La mission créatrice : plans, ego, réincarnation / Georges Chevrier, Paris, Publications théosophiques, 1917.

FLó Juan, Torres-García: desde Montevideo, Arca, 1991.

FLo Juan, “Malos tiempos para Joaquín Torres García. Juan Fló”, Museo Torres García, publicado por primera vez en Brecha, 20 de agosto de 2004. http://www.torresgarcia.org.uy/uc_7....

HARTMANN Franz, La magie blanche et noire, ou la science de la vie terrestre et de la vie infinie contenant des conseils pratiques pour les étudiants de l'occultisme, Libr. de l'Art indépendant, 1903.

La Escuela del Sur: el Taller Torres-García y su legado : Museo Nacional Centro de Arte Reina Sofía, julioagosto 1991. Ministerio de Cultura, 1991.

LIDDELL Henry George, scoTT Robert, LIDDELL Henry George, A Greek-English Lexicon, Oxford; New York, Oxford University Press, 1943.

MONLAUR Reynés, TORRES-GARCíA Joaquín, El rayo de luz : escenas evangélicas, Gustavo Gili, 1916.

DI MAGGIO Nelson, “ Torres García en edición de lujo ”, in LARED21. Consulté le 7 février 2014.

http://www.lr21.com.uy/cultura/2893....

PAPUS, Ce que deviennent nos morts ; suivi de Méditations sur le "Pater " et de quelques opuscules posthumes / Papus (Dr Encausse), Paris, La Sirène, 1918. 
PRAT Marie-Aline, Peinture et avant-garde au seuil des années 30, Paris, Age d'homme, 1984.

REVEL Gaston, De l'an 25.000 avant Jésus-Christ à nos jours / Gaston Revel, Paris, les Éditions théosophiques, 1913.

SAINT-YVES D'ALVEYDRE Alexandre, L'archéomètre, clef de toutes les religions et de toutes les sciences de l'antiquité, réforme synthétique de tous les arts contemporains... / Saint-Yves d'Alveydre, Paris, Dorbon aîné, 1910.

SCHURÉ Édouard, L'évolution divine : du sphinx au Christ / Édouard Schuré, Paris, Perrin, 1912.

STEINE Rudolf, Théosophie : étude sur la connaissance suprasensible et la destinée humaine / Rudolf Steiner ; traduit de l'allemand, par Elsa Prozor, Paris, Les Presses universitaires de France, 1923.

TORRES-GARCíA Joaquín, Père Soleil. Texto fechado por el autor en París, el 29 de julio 1931. Escrito en francés. Primera edición : Fundación Torres-García, Montevideo, 1974. Formato 17 x 12,5 cm, 72 páginas no numeradas

TORRES-GARCÍA Joaquín, Universalismo constructivo, Alianza, 1984.

VIDAL Edgard, “Joaquín Torres García, ¿teósofo ? ”, in ARTE, EL PAIS. Febrero 2014. http://

www.academia.edu/6182882/

\section{NOTAS}

1. En las primeras décadas del siglo XX éstas ideas son objeto de análisis y de discusión en los salones, librerías y en la prensa cotidiana francesa. Es así que se organiza el primer Congreso Teosófico de París en 1900. También, gracias al activismo de la familia Revel, se crean editoriales y revistas específicas. Esta familia tiene un rol importante en la difusión de la teosofía en Francia. Liévin Revel es un ingeniero que se ocupa de minas de nickel y hierro en Nueva Caledonia, perdiendo tres hijos y volviendo al puerto del Havre en 1887. Allí Liévin se vuelve teósofo, conociendo personalmente a Mme. Blavatsky. Instalada la familia en París, sus hijos Gaston y Louis participan en la creación de la Sociedad Teosófica. Gastón crea una revista llamada 'Le téosophe' donde serán publicados muchos artículos leídos también por la comunidad de artistas de París. A esto se agrega que Gastón Revel compra la librería creada por Edmond Bailly, donde se reunían poetas, pintores y músicos del período simbolista como Mallarmé, Odilon Redon o Debussy.

2. « Harmonia », en A Greek-English Lexicon. Oxford; New York : Oxford University Press.

3. En 1893 Torres García (tenia entonces 19 años) se matriculó en el Círculo Artístico de Sant Lluc, de perfil católico, del que se imbuiría -como constatado en nuestro análisis- de manera prolongada. En todo del Circulo será socio hasta el año 1898. Allí, a partir del año 1894 participó en las Exposiciones Generales de Bellas Artes, en la sección Extranjera. En 1897 expuso sus obras en la sala de exposiciones del periódico La Vanguardia, y participó en una exposición colectiva de los Socios del Círculo Artístico de Sant Lluc.

4. Georges Chevrier utiliza el termino de Ego, separándolo de la individualidad divina, para asignarlo a la forma humana en el contexto de la doctrina kármica (Chevrier, 1917: 38-40). 


\section{RESÚMENES}

Este artículo se propone estudiar las interrelaciones entre la obra constructiva y el pensamiento esotérico en la obra de Joaquín Torres-García, concentrándose sobre un momento importante en la vida del pintor, el libro "Père Soleil", escrito en Paris y firmado por el autor en 1931. A partir de una base de datos lexicales de los términos con letras mayúsculas, son descubiertas numerosas correlaciones de este texto con el corpus teosófico francés de fines del siglo XIX y principios del siglo XX.

L'article se propose d'étudier les interrelations de l'œuvre constructive avec la pensée ésotérique dans les travaux de Joaquín Torres García, en se concentrant sur le livre Père Soleil, écrit à Paris au cours de l'été de 1931. À partir d'une base de données lexicale des termes écrits en majuscules, sont mises en évidence de nombreuses corrélations avec le corpus théosophique de la fin du XIXe et du début du XXe siècle.

\section{ÍNDICE}

Mots-clés: Joaquín Torres García, "Père Soleil", théosophie, analyse lexicale

Palabras claves: Joaquín Torres-García, Père Soleil, teosofía, análisis lexical

\section{AUTOR}

EDGARD VIDAL

CRAL-EFISAL 